\title{
Cross-Country Productivity Growth
}

\section{Riccardo DiCecio}

A verage labor productivity-i.e., the amount of output produced per unit of labor-is a key determinant of the long-run economic performance of a country. Over the past 10 years, productivity growth rates among national economies have contrasted strikingly: productivity grew at an average annual rate of 2.3 percent for the United States, 1.7 percent for the United Kingdom, 1.4 percent for Japan, and 0.9 percent for the euro area.

Labor productivity growth rates could differ among countries according to where each country is along the business cycle. Also, faster technological progress or a greater capital intensity (i.e., workers using more machines to produce things) could have generated faster productivity growth in the United States. In a recent study, ${ }^{1}$ Skoczylas and Tissot analyzed productivity developments across industrial countries and argue that, even when differences in the business cycles or capital intensity are taken into account, U.S. productivity growth rates stand out in any international assessment. ${ }^{2}$

Many analysts have cited the IT revolution as a possible explanation of the high rate of U.S. productivity growth. But the U.S. advantage in average labor productivity has persisted despite the recent slump in IT investment in the United States and the sustained rates of investment in IT in other industrialized countries. This fact makes it less likely that the IT revolution is the sole explanation of U.S. productivity growth.

Legal and cultural flexibility in economic relationships, however, might help explain the higher U.S. productivity growth. Since the 1970s, U.S. economic laws and regulations have fostered increasing flexibility compared with those of its industrialized trading partners. For example, U.S. firms find it is easier and cheaper to hire (and fire) workers and to start (and end) a business activity. This flexibility makes it easier for markets to relocate workers from lower-productivity firms and sectors to more productive occupations. Also, more competitive markets for goods and services can provide greater incentives for technological innovation and adoption as firms strive to keep ahead of their competitors. The U.S. retail sector, for example, leads the world partly because it is so competitive domestically.

The experience of the United Kingdom, which undertook structural reforms similar to those of the United States, supports the view that economic flexibility has contributed to U.S. productivity growth rates. Like the United States, the United Kingdom has experienced not only a sharp decline in manufacturing's share of total employment but also better labor productivity growth than most countries. ${ }^{3}$

Nobel laureate Ed Prescott suggests a different explanation: Lower taxes on labor income make Americans more willing to work. ${ }^{4}$ Prescott observes that differences in hours worked per person explain most of the differences in output per worker across industrialized countries in the 1990s. On the other hand, output per hour worked is similar across countries.

In the past, persistent differences in productivity across industrial countries have typically been reversed. Yet, while U.S. productivity growth has slowed recently, there is little evidence of faster productivity growth in the euro area or Japan. Hence, the differences evident in the chart are likely to persist in the near future.

\footnotetext{
${ }^{1}$ Les Skoczylas and Bruno Tissot, "Revisiting Recent Productivity Developments across OECD Countries," Working Paper No. 182, Bank for International Settlements, October 2005.

${ }^{2}$ Skoczylas and Tissot discuss the measurement issues that make it difficult to study productivity at the national level and complicate cross-country comparisons.

${ }^{3}$ See "Industrial Metamorphosis," The Economist, October 1, 2005.

${ }^{4}$ Edward C. Prescott, "Why Americans Work So Much," Federal Reserve Bank of Minneapolis Quarterly Review, July 2004, 28(1), pp. 2-13.
}

\section{Labor Productivity (output per worker, $1995=100$ )}

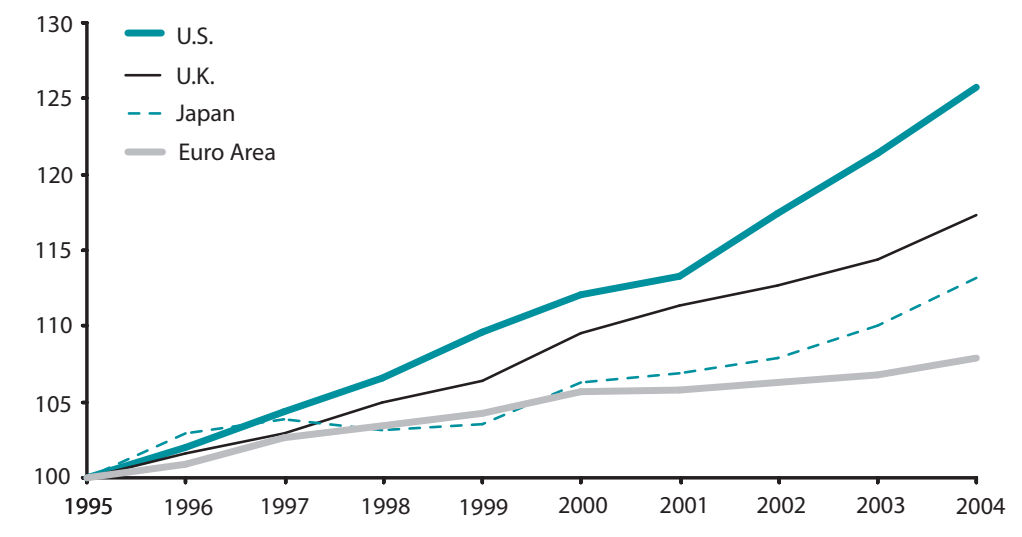

